\title{
Pemberdayaan Masyarakat dalam Rehabilitasi Hutan dan Lahan melalui Program Kebun Bibit Rakyat di Desa Sumberrejo Kecamatan Tempel Kabupaten Sleman
}

\author{
Aris Wibawa1 \\ Diterima : 24 Maret 2014 \\ Disetujui : 7 April 2014
}

\begin{abstract}
The problem of critical and less productive land in Sumberrejo village, Tempel sub district, Sleman district is chosen as the research location because it is adjacent to the Krasak river, which also support the quality and function of its sub river basin (sub DAS). This research uses the combination of qualitative and quantitative methods. The result shows that the form of effort in the community enpowerment which is done in the KBR programme is able to increase the farmer group capacity especially at the aspects of technique, institute, administration and entrepreneur. The society participation at the planning step for the programme planning is at the informing level and the planning of activity implementation is at the delegated power level and consultation level for the policy maker. At the action step for the power mobilization is at the delegated power level and problem solving is at the consultation level. The evaluation step with monitoring variable at the partnership level and evaluation is at the consultation level. The planting successfulness level with realization of the wide planting area and the realization of planting growth is in the criteria success. The KBR programme implies in increasing potency of the society welfare.
\end{abstract}

Keywords: community empowerment, rehabilitation, infertile land

\begin{abstract}
ABSTRAK
Permasalahan lahan kritis dan lahan kurang produktif di Desa Sumberrejo, Kecamatan Tempel, Kabupaten Sleman dipilih sebagai lokasi penelitian karena berbatasan langsung dengan Sungai Krasak, yang turut mendukung fungsi Sub Daerah Aliran Sungainya. Penelitian ini menggunakan metode kualitatif dan kuantitatif. Kesimpulan menunjukkan bahwa bentuk-bentuk upaya pemberdayaan masyarakat yang dilakukan pada Program KBR ternyata mampu meningkatkan kapasitas kelompok tani pada aspek teknis, kelembagaan, administrasi serta kewirausahaan. Tingkat partisipasi masyarakat pada tahap perencanaan untuk variabel perencanaan program berada pada level informing dan perencanaan implementasi kegiatan pada level delegated power serta level consultation untuk pengambilan keputusan. Pada tahap pelaksanaan, untuk mobilisasi tenaga pada level delegated power dan penyelesaian masalah pada level consultation. Tahap evaluasi, dengan variabel monitoring pada level partnership, dan evaluasi pada level consultation. Tingkat keberhasilan penanaman, dengan realisasi luas areal tanam dan realisasi pertumbuhan tanaman masuk kriteria berhasil. Program KBR berimplikasi terhadap peningkatan potensi kesejahteraan masyarakat.
\end{abstract}

Kata kunci : pemberdayaan masyarakat, rehabilitasi, lahan kritis

\footnotetext{
${ }^{1}$ Pemerintah Kabupaten Sleman

Kontak Penulis: ariswibawa3@gmail.com
} 


\section{PENDAHULUAN}

Sejalan dengan perkembangan jumlah penduduk dan kegiatan pembangunan di Indonesia mengakibatkan peningkatan eksploitasi terhadap sumberdaya alam. Sumberdaya hutan sebagai salah satu sumberdaya alam juga tak luput dari eksploitasi yang semakin meningkat. Eksploitasi terhadap sumberdaya hutan ini terjadi baik di hutan yang berstatus hutan negara maupun yang berupa lahan hak milik atau sering disebut hutan rakyat.

Tekanan terhadap hutan rakyat yang semakin besar ini disebabkan oleh semakin meningkatnya kebutuhan akan kayu hasil hutan rakyat sebagai akibat semakin mahalnya kayu rimba luar Jawa dan kayu Jati dari Perhutani. Sebab lain yaitu tuntutan kebutuhan ekonomi untuk memenuhi biaya pendidikan anak, untuk biaya hidup bahkan untuk dana sosial kemasyarakatan. Eksploitasi yang berlebihan terhadap sumberdaya hutan ini mengakibatkan penurunan kualitas maupun kuantitasnya. Penurunan kualitas hutan yang ditandai dengan berkurangnya penutupan hutan akan meningkatkan nilai kekritisan lahan, apalagi pada lahan-lahan yang secara topografi, kemiringan lahannya memang sudah kritis.

Berdasarkan hasil peninjauan kembali (review) data lahan kritis, total luas lahan kritis di Indonesia sebesar 82,1 juta $\mathrm{Ha}$, dengan rincian luas lahan sangat kritis dan kritis adalah 29,9 juta $\mathrm{Ha}$, sedangkan luas lahan agak kritis 52,2 juta Ha. Lahan sangat kritis dan kritis seluas 29,9 juta Ha tersebut merupakan sasaran indikatif RHL yang diprioritaskan untuk segera direhabilitasi. Sementara itu Kementerian Kehutanan sejak tahun 2010 menetapkan program peningkatan fungsi dan daya dukung DAS berbasis pemberdayaan masyarakat pada 108 DAS prioritas.

Dalam perkembangannya untuk lebih mengkomprehensipkan dan mengintegralkan kegiatan Rehabilitasi Hutan dan Lahan (RHL) pemerintah mengeluarkan Peraturan Menteri Kehutanan Republik Indonesia Nomor P.12/ Menhut-II/2011 tanggal 9 Maret 2011 tentang Pedoman Penyelenggaraan Rehabilitasi Hutan dan Lahan Tahun 2011. Sejalan dengan itu dalam rangka efisiensi dan efektifitas dalam pelaksanaan pembangunan Kebun Bibit Rakyat dikeluarkan Peraturan Menteri Kehutanan Republik Indonesia Nomor P.23/Menhut-II/2011 tanggal 8 April 2011 tentang Pedoman Teknis Kebun Bibit Rakyat.

Permasalahan lahan kritis dan lahan kurang produktif di Desa Sumberrejo, Kecamatan Tempel, Kabupaten Sleman dipilih sebagai lokasi penelitian karena berbatasan langsung dengan Sungai Krasak, yang turut mendukung kualitas dan fungsi Sub Daerah Aliran Sungainya. Setidaknya ada 2 (dua) kendala dalam RHL yaitu masyarakat yang kurang berdaya atau tidak mempunyai kemampuan dalam penanganan lahan kritis, di sisi lain kemampuan pemerintah sangat terbatas dalam penanganan lahan kritis. Upaya pemerintah untuk mendorong dan meningkatkan kemampuan masyarakat dalam RHL, salah satunya dengan memberdayakan masyarakat dalam pengadaan bibit berkualitas melalui Pembangunan Kebun Bibit Rakyat (KBR).

\section{METODE PENELITIAN}

Penelitian ini menggunakan kombinasi metode kualitatif dan kuantitatif. Pada aspek pemberdayaan masyarakat dan tingkat partisipasi masyarakat menggunakan metode kualitatif, sedangkan pada aspek tingkat keberhasilan penanaman dan potensi peningkatan kesejahteraan masyarakat menggunakan metode kuantitatif. Hal ini sejalan dengan pemikiran Prasetyo dan Miftahul Jannah (2012) bahwa dalam satu penelitian yang sama, kita bisa 
menerapkan kedua metode yang ada yaitu metode kualitatif dan metode kuantitatif, yang akhirnya menghasilkan data kualitatif dan data kuantitatif.

\section{GAMBARAN UMUM}

Desa Sumberrejo yang berada sekitar $4 \mathrm{~km}$ arah Selatan Kecamatan Tempel dan $8 \mathrm{Km}$ arah Barat Laut ibukota Kabupaten Sleman. Wilayah Desa Sumberrejo secara geografis berada pada ketinggian $250 \mathrm{~m}$ dari permukaan air laut dengan curah hujan rata-rata $1.900 \mathrm{~mm} /$ tahun, serta suhu rata-rata per tahun adalah $26-37^{\circ} \mathrm{C}$. Desa Sumberrejo dilalui Sungai Mlinting di sebelah timur dan Sungai Krasak di sebelah barat. Sungai-sungai ini merupakan bagian (sub DAS) dari DAS Progo.

Secara administrasi Desa Sumberrejo terletak di Kecamatan Tempel, Kabupaten Sleman dengan batas-batas sebagai berikut :

- Sebelah utara yaitu berbatasan dengan Desa Pondokrejo, Tempel, Sleman,

- Sebelah selatan yaitu berbatasan dengan Desa Banyurejo, Tempel, Sleman,

- Sebelah barat yaitu berbatasan dengan Kabupaten Magelang, serta

- Sebelah timur yaitu berbatasan dengan Desa Tambakrejo.

Wilayah Desa Sumberrejo terdiri dari 10 padukuhan yang terbagi menjadi 21 dusun 22 RW dan 45 RT.

Implikasi dari posisi Kecamatan Tempel yang berada di sisi Utara, daerah ini merupakan daerah tangkapan air bagi Kabupaten Sleman bagian Selatan bahkan bagi Kota Yogyakarta dan Kabupaten Bantul. Kondisi di wilayah hulu ini sangat berpengaruh terhadap kondisi di wilayah hilir terutama permasalahan airnya. Khusus Desa Sumberrejo yang sisi Baratnya berbatasan dengan Sungai Krasak, maka sepanjang arah Utara-Selatan di Desa Sumberrejo memiliki lahan sempadan sungai yang turut mendukung kualitas dan fungsi Sub Daerah Aliran Sungainya.

Desa Sumberrejo merupakan 1 (satu) di antara 15 (lima belas) desa di Kabupaten Sleman yang melaksanakan Program Kebun Bibit Rakyat untuk tahun 2011/2012. Program KBR di Desa Sumberrejo Kecamatan Tempel ini dilaksanakan oleh Kelompok Tani Sumber Rejeki. Kelompok tani ini selanjutnya menurut Permenhut Nomor P.23/Menhut-II/2011 disebut Kelompok Masyarakat Pelaksana KBR yaitu kelompok masyarakat yang menyusun rencana, melaksanakan dan mengawasi pembangunan KBR.

Lokasi persemaian Program Kebun Bibit Rakyat Desa Sumberrejo ini terletak di blok tegalan Dusun Jetis, Desa Sumberrejo. Berdasarkan Rencana Usulan Kegiatan Kelompok (RUKK) yang disusun oleh kelompok tani itu sendiri, disepakati bibit yang dibuat adalah bibit Sengon dan Mahoni. Kedua jenis bibit itu dipilih setelah melalui musyawarah dan berbagai pertimbangan. Berdasarkan pengalaman kedua jenis bibit tersebut cocok tumbuh di Desa Sumberrejo dan sekitarnya. Pertimbangan teknis pembibitan, bahwa benih/biji dari kedua jenis tanaman tersebut relatif mudah untuk disemaikan. Selain itu pertimbangan ekonomis dan lingkungan, Sengon termasuk daur pendek sehingga cepat panen, sedangkan Mahoni relatif berdaur panjang sehingga fungsi ekologisnya diharapkan berlangsung lama.

Proses pelaksanaan pembuatan bibit dimulai pada sekitar Bulan Agustus 2011 dan bibit siap tanam pada kisaran bulan Februari 2012. Pada kelompok masyarakat pelaksana KBR dibagi kedalam 3 (tiga) tim yaitu Tim Perencana, Tim Pelaksana, dan Tim Pengawas. Selama proses 
program ini dilakukan upaya-upaya peningkatan pengetahuan dan ketrampilan teknis kepada petani melalui pelatihan dan pendampingan oleh petugas terkait. Selain itu dilakukan juga pembinaan penguatan kelembagaan kelompok tani. Kegiatan pendampingan di lapangan ini terutama dilakukan oleh Petugas Lapangan Rehabilitasi Hutan dan Lahan (PL-RHL). Dokumentasi berupa foto-foto pada saat pelaksanaan kegiatan Program KBR di Desa Sumberrejo, Kecamatan Tempel, Kabupaten Sleman menunjukkan partisipasi langsung secara aktif oleh masyarakat secara menyeluruh baik laki-laki perempuan, tua dan muda pada berbagai tahapan kegiatan Program KBR.

\section{KAJIAN TEORI}

Pemberdayaan (empowerment) berasal dari Bahasa Inggris power yang diartikan kekuasaan atau kekuatan. Menurut Paul (1987) pemberdayaan berarti pembagian kekuasaan yang adil (equatable sharing of power) sehingga meningkatkan kesadaran politik atau kekuasaan kelompok yang lemah serta memperbesar pengaruh mereka terhadap proses dan hasil-hasil pembangunan. Sedangkan menurut Robert Dahl (1983) pemberdayaan diartikan sebagai pemberian kuasa untuk mempengaruhi atau mengontrol.

Pemberdayaan masyarakat adalah usaha untuk membangun, menguatkan, dan mengembangkan kelembagaan serta dilakukan pendampingan secara berkelanjutan menuju ke arah kemandirian (Suhartini,dkk. 2005). Pemberdayaan adalah sebuah proses dan sebuah tujuan. Sebagai proses pemberdayaan adalah serangkaian aktivitas untuk memberikan kekuasaan kepada kelompok lemah untuk memperoleh akses dan kesempatan yang sama seperti yang didapat kelompok kuat. Sedangkan pemberdayaan sebagai tujuan dapat dilihat sebagai hasil dari suatu proses untuk menciptakan masyarakat yang mampu dan berdaya , berkuasa terhadap diri sendiri, mampu memenuhi kebutuhan hidup sendiri sehingga mendapatkan kehidupan yang lebih baik secara ekonomi, fisik dan sosial.

Partisipasi masyarakat sering diartikan sebagai keikutsertaan dan keterlibatan anggota masyarakat dalam suatu kegiatan tertentu, baik secara langsung maupun tidak langsung. Menurut Adisasmita (2006) partisipasi anggota masyarakat didefinisikan sebagai keterlibatan dan pelibatan anggota masyarakat dalam pembangunan meliputi kegiatan dalam perencanaan dan pelaksanaan (implementasi) program/proyek pembangunan yang dikerjakan di masyarakat lokal. Sedangkan Hall (1986) berpendapat bahwa partisipasi masyarakat merupakan pendekatan pembangunan yang memandang masyarakat dalam konteks yang dinamis yang mampu memobilisasi sumberdaya yang ada sesuai dengan kepentingan, kemampuan, dan aspirasi yang dimiliki baik secara individu maupun komunal.

Menurut Arnstein (1969) dalam Legates (1999), partisipasi masyarakat dalam pembangunan terbagi ke dalam 8 (delapan) tingkatan yaitu : 1. Manipulation atau manipulasi; 2. Therapy atau terapi; 3. Informing atau pemberian informasi; 4. Consultation atau konsultasi; 5. Placation atau perujukan; 6. Partnership atau kemitraan; 7. Delegated Power atau pelimpahan kekuasaan; dan 8.Citizen Control atau masyarakat yang mengontrol. Kedelapan tingkatan partisipasi ini secara garis besar, dibagi dalam 3 (tiga) kelompok besar yaitu pertama Non Participation (ketidakikutsertaan) meliputi Manipulation dan Therapy; kedua Tokenism (tokenisme/partisipasi semu) meliputi Informing, Consultation, dan Placation; ketiga Citizen Power (kekuatan masyarakat) meliputi Partnership, Delegated Power, dan Citizen Control. 
Kedelapan tangga tingkatan partisipasi masyarakat itu dapat dilihat seperti dalam Tabel 1 berikut ini :

TABEL 1

TANGGA PARTISIPASI MENURUT ARNSTEIN

\begin{tabular}{|c|c|c|c|}
\hline No. & $\begin{array}{l}\text { Tangga/Tingkatan } \\
\text { Partisipasi }\end{array}$ & Hakekat keikutsertaan & $\begin{array}{l}\text { Tingkatan } \\
\text { Pembagian } \\
\text { Kekuasaan }\end{array}$ \\
\hline 8 & $\begin{array}{c}\text { Citizen control } \\
\text { (Kontrol masyarakat) }\end{array}$ & $\begin{array}{l}\text { Masyarakat mempunyai kekuasaan penuh } \\
\text { mengatur program }\end{array}$ & \multirow{3}{*}{$\begin{array}{c}\text { Tingkatan } \\
\text { kekuatan } \\
\text { masyarakat } \\
\text { (Citizen Power) }\end{array}$} \\
\hline 7 & $\begin{array}{l}\text { Delegated power } \\
\text { (Pelimpahan } \\
\text { kekuasaan) }\end{array}$ & $\begin{array}{l}\text { Masyarakat diberi kekuasaan untuk } \\
\text { sebagian atau seluruh program }\end{array}$ & \\
\hline 6 & $\begin{array}{l}\text { Partnership } \\
\text { (Kemitraan) }\end{array}$ & $\begin{array}{l}\text { Kekuasaan didistribusikan melalui } \\
\text { negosiasi antara warga dan pemegang } \\
\text { kekuasaan }\end{array}$ & \\
\hline 5 & $\begin{array}{l}\text { Placation } \\
\text { (Perujukan) }\end{array}$ & $\begin{array}{l}\text { Masyarakat mulai berpengaruh, } \\
\text { ditempatkan di dewan publik meski diikuti } \\
\text { strategi ditenangkan/dikalahkan suaranya }\end{array}$ & \multirow[t]{3}{*}{ Tokenisme } \\
\hline 4 & $\begin{array}{l}\text { Consultation } \\
\text { (Konsultasi) }\end{array}$ & $\begin{array}{l}\text { Pendapat masyarakat didengar tetapi ide- } \\
\text { idenya tidak selalu dipakai }\end{array}$ & \\
\hline 3 & $\begin{array}{c}\text { Informing } \\
\text { (Pemberian informasi) }\end{array}$ & $\begin{array}{l}\text { Hak-hak masyarakat dan pilihan-pilihannya } \\
\text { diidentifikasikan }\end{array}$ & \\
\hline 2 & $\begin{array}{l}\text { Therapy } \\
\text { (Terapi) }\end{array}$ & $\begin{array}{l}\text { Pemegang kekuasaan mendidik atau } \\
\text { mengobati masyarakat }\end{array}$ & \multirow{2}{*}{$\begin{array}{l}\text { Tidak ada } \\
\text { partisipasi (Non } \\
\text { Participation) }\end{array}$} \\
\hline 1 & $\begin{array}{l}\text { Manipulation } \\
\text { (Manipulasi) }\end{array}$ & $\begin{array}{l}\text { Terjadi manipulasi partisipasi masyarakat, } \\
\text { dikenal dengan Komite berstempel }\end{array}$ & \\
\hline
\end{tabular}

Sumber : Arnstein (1969) dalam LeGates (1999)

\section{Kesejahteraan Masyarakat}

Definisi umum kemiskinan adalah kurangnya kesejahteraan. Sejalan dengan pengertian tersebut Sulistiyani (2004) menyatakan bahwa kesejahteraan adalah kondisi yang berbading terbalik dengan kondisi kemiskinan. Menurutnya kemiskinan bukan sekedar kekurangan dalam pemenuhan kebutuhan minimal, akan tetapi juga berarti kerentanan dan rendahnya beberapa akses dalam kepentingan publik.

Pada umumnya kemiskinan diukur dengan tingkat pendapatan dan kebutuhan. Kebutuhan hanya dibatasi pada kebutuhan pokok atau kebutuhan dasar minimum yang memungkinankan seseorang dapat hidup layak. Jika tingkat pendapatan tidak dapat memenuhi kebutuhan minimum, maka orang atau rumah tangga tersebut dikatakan miskin (Agung, 2001).

John Friedmann dalam Agung (2001) mendefinisikan kemiskinan sebagai ketidaksamaan kesempatan untuk mengakumulasi basis kekuasaan sosial. Basis kekuasaan sosial antara lain meliputi : modal yang produktif atau assets (misalnya tanah, perumahan, peralatan, pohon/tanaman, dll); sumber-sumber keuangan (income dan kredit yang memadai); organisasi sosial dan politik yang dapat digunakan untuk mencapai kepentingan bersama; network atau jaringan sosial untuk memperoleh pekerjaan, barang-barang, dll; pengetahuan dan ketrampilan yang memadai dan informasi yang berguna untuk memajukan kehidupan.

\section{Rehabilitasi Hutan dan Lahan}

Rehabilitasi lahan adalah kegiatan yang secara sengaja ditujukan untuk regenerasi pohon, baik secara alami dan atau buatan, pada padang rumput, semak belukar, atau wilayah tandus yang 
dulunya merupakan hutan, dengan tujuan untuk meningkatkan produktifitas, penghidupan masyarakat, dan atau manfaat jasa lingkungan (Tim CIFOR 2003 dalam Nawir et all, 2008). Sedangkan menurut Permenhut Nomor P.70/Menhut-II/2008, Rehabilitasi Hutan dan Lahan $(\mathrm{RHL})$ adalah upaya untuk memulihkan, mempertahankan dan meningkatkan fungsi hutan dan lahan sehingga daya dukung, produktivitas dan peranannya dalam mendukung penyangga kehidupan tetap terjaga.

Rehabilitasi hutan dan lahan merupakan upaya pengembangan fungsi sumberdaya hutan dan lahan, baik fungsi produksi maupun fungsi lindung dan konservasi. Menurut Kementerian Kehutanan, rehabilitasi terdiri atas dua kategori yaitu reboisasi dan penghijauan. Reboisasi atau rehabilitasi hutan didefinisikan sebagai kegiatan menanam pohon yang dilaksanakan di dalam kawasan hutan, sedangkan penghijauan atau rehabilitasi lahan berkenaan dengan penanaman pohon yang dilaksanakan di lahan hak milik masyarakat di luar kawasan hutan.

Secara umum bahwa keberadaan lahan tidak terlepas dari Daerah Aliran Sungai yang melingkupinya. Menurut Undang-undang RI No. 7 Tahun 2004 tentang Sumber Daya Air, definisi Daerah Aliran Sungai (DAS) adalah suatu wilayah daratan yang merupakan satu kesatuan dengan sungai dan anak-anak sungainya, yang berfungsi menampung, menyimpan, dan mengalirkan air yang berasal dari curah hujan ke danau atau ke laut secara alami, yang batas di darat merupakan pemisah topografis dan batas di laut sampai dengan daerah perairan yang masih terpengaruh aktivitas daratan.

\section{Kebun Bibit Rakyat (KBR)}

Berdasarkan Pendahuluan Permenhut RI P.23/Menhut-II/2011 Tentang Pedoman Penyelenggaraan KBR, Kebun Bibit Rakyat merupakan program pemerintah untuk menyediakan bibit tanaman hutan dan jenis tanaman serbaguna (multi purpose tree species/MPTS) yang dilaksanakan secara swakelola oleh kelompok masyarakat, terutama di perdesaan. Bibit hasil Kebun Bibit Rakyat digunakan untuk merehabilitasi hutan dan lahan kritis serta kegiatan penghijauan lingkungan. Jenis tanaman serbaguna adalah jenis tanaman yang menghasilkan kayu dan bukan kayu (buah-buahan, getah, kulit, minyak atsiri, dll.). Pelaksanaan program KBR berdasarkan Permenhut RI P.23/Menhut-II/2011 tentang Pedoman Penyelenggaraan KBR.

\section{ANALISIS}

\section{Analisis Bentuk-bentuk Upaya Pemberdayaan Masyarakat}

Pemberdayaan dapat dimaknai sebagai suatu proses menuju berdaya atau lebih berdaya. Pada umumnya proses memperoleh daya, kekuatan atau kemampuan melalui proses pemberian kekuasaan, daya, kekuatan dan atau kemampuan dari pihak yang memiliki daya kepada pihak yang kurang atau belum berdaya. Pemberdayaan juga merupakan upaya menciptakan kondisi yang memungkinkan potensi masyarakat tergali dan berkembang.

Upaya pemberdayaan ini, harus dimulai dari pemahaman bahwa setiap masyarakat itu pada dasarnya memiliki daya, berapa pun kecilnya atau bahkan yang masih berupa potensi daya. Jangankan pada masyarakat yang masih terbelakang, pada masyarakat yang telah lebih maju pun, seringkali mereka tidak menyadari bahwa mereka memiliki daya atau kemampuan. Untuk itulah diperlukan langkah-langkah atau bentuk-bentuk upaya agar potensi daya masyarakat dapat digali dan dikembangkan dalam rangka memperoleh serta meningkatkan daya atau kemampuan masyarakat sehingga masyarakat lebih mampu untuk mandiri. 
Hasil pengidentifikasian terhadap upaya-upaya pemberdayaan masyarakat dalam Program KBR mendapatkan hasil bahwa bentuk upaya pemberdayaan masyarakat yang dilakukan berupa : a. pemberian kewenangan kepada masyarakat; b. pemberian dana dan insentif kegiatan; c. pendidikan dan latihan; d. bimbingan teknis; e. pendampingan; f. pengembangan kesempatan berusaha dan g. pengembangan akses.

\section{Implikasi Pemberdayaan Masyarakat terhadap Kapasitas Kelompok Tani}

Kegiatan KBR khususnya dan RHL pada umumnya sangat terkait dengan keberadaan masyarakat, baik sebagai individu maupun sebagai anggota kelompok. Untuk itu peranserta masyarakat tersebut harus didorong secara berkelanjutan, dengan meningkatkan kemampuan dan kemandirian mereka demi kesinambungan kegiatan RHL. Kenyataan bahwa tanpa peranserta aktif masyarakat, kegiatan RHL akan menjadi beban pemerintah yang teramat berat. Diharapkan selanjutnya kegiatan RHL benar-benar dapat menjadi tanggungjawab bersama antara masyarakat dan pemerintah.

Berdasarkan jawaban dan informasi dari informan dapat dirumuskan atau dikelompokkan peningkatan kapasitas itu ke beberapa aspek berikut ini :

1. Aspek teknis

Peningkatan kapasitas kelompok tani dari aspek teknis ini antara lain ditunjukkan dengan petani menjadi lebih tahu teknik perbenihan, cara pembibitan dan penanaman, pengetahuan teknik pembuatan tanaman meningkat.

2. Aspek kelembagaan

Peningkatan kapasitas kelompok tani dari aspek kelembagaan ini antara lain ditunjukkan dengan organiasasi kelompok tani yang lebih tertata, organisasi bisa berjalan lebih baik, bisa bekerja sebagai tim yang solid.

3. Aspek administrasi

Peningkatan kapasitas kelompok tani dari aspek administrasi ini antara lain ditunjukkan dengan petani mendapatkan tambahan pengetahuan administrasi keuangan, administrasi laporan kegiatan juga semakin baik.

4. Aspek lainnya

Aspek lain terutama aspek kewirausahaan : terbukanya wawasan dan ide baru bahwa kegiatan pembibitan dapat dijadikan sebagai bidang usaha baru

\section{Analisis Tingkat Partisipasi Masyarakat}

Membicarakan pemberdayaan masyarakat tidak dapat dipisahkan dengan partisipasi masyarakat karena keduanya berkaitan. Pemberdayaan biasanya berada pada tingkat partisipasi yang relatif tinggi. Analisis pada sub bab ini pun bertujuan untuk mengkaji tingkat partisipasi masyarakat dalam Rehabilitasi Hutan dan Lahan melalui Program Kebun Bibit Rakyat (KBR) di Desa Sumberrejo, Kecamatan Tempel, Kabupaten Sleman meliputi tahapan perencanaan, pelaksanaan dan evaluasi. Untuk keperluan analisis pengindentifikasian tingkat partisipasi masyarakat ini menggunakan 8 (delapan) tangga partisipasi dari Sherry Arstein.

Hasil dan analisis partisipasi masyarakat dalam Program KBR di Desa Sumberrejo Kecamatan Tempel Kabupaten Sleman menunjukkan :

a. Pada tahap perencanaan, tingkat partisipasi masyarakat untuk variabel perencanaan program berada pada level informing dan untuk perencanaan implementasi kegiatan pada level delegated power. Untuk variabel pengambilan keputusan dalam perencanaan ini tingkat partisipasi masyarakat berada pada level consultation. 
b. Pada tahap pelaksanaan, tingkat partisipasi masyarakat untuk variabel mobilisasi tenaga berada pada level delegated power. Untuk variabel penyelesaian masalah tingkat partisipasi masyarakat berada pada level consultation.

c. Tahap monitoring dan evaluasi yang masing-masing dengan variabel monitoring berada pada level partnership, sedangkan untuk evaluasi berada pada level consultation.

\section{Analisis Tingkat Keberhasilan Penanaman}

Menurut Peraturan Menteri Kehutanan Republik Indonesia Nomor P.70/Menhut-II/2008 Tentang Pedoman Teknis Rehabilitasi Hutan dan Lahan, Evaluasi tanaman dimaksudkan untuk mengetahui tingkat keberhasilan pembuatan tanaman. Adapun tujuannya adalah teridentifikasinya kondisi fisik tanaman sebagai dasar pengelolaan Rehabilitasi Hutan dan Lahan (RHL) lebih lanjut. Tingkat keberhasilan pembuatan tanaman menurut Permenhut Nomor P.70/Menhut-II/2008 ini dapat diukur berdasarkan beberapa indikator antara lain realisasi luas areal tanam dan realisasi tingkat pertumbuhan tanaman.

Untuk tingkat keberhasilan penanaman, dengan melihat prosentase realisasi luas areal tanam yang mencapai $100 \%$ berarti termasuk kriteria berhasil ( $\geq 80 \%)$; sedangkan realisasi pertumbuhan tanaman yang mencapai $99,10 \%$ berarti termasuk kriteria berhasil ( $260 \%$ untuk penilaian tahap I).

\section{Analisis Potensi Peningkatan Kesejahteraan Masyarakat}

Mengingat karakteristik dari komoditas tanaman kehutanan yang berdaur panjang dan pada saat penelitian belum waktunya panen, maka analisis untuk tingkat kesejahteraan masyarakat, dilakukan khusus untuk potensi peningkatan kesejahteraan masyarakat. Analisis potensi peningkatan kesejahteraan masyarakat yang diukur pada penelitian ini terutama peningkatan aset/kekayaan berupa pohon dan potensi sebagai tambahan pendapatan pada waktu panen nanti serta ada tidaknya peluang mata pencaharian baru.

Ada implikasi Program KBR terhadap potensi peningkatan kesejahteraan masyarakat berupa peningkatan jumlah kekayaan/asset berupa pohon, potensi tanaman bibit KBR sebagai tambahan pendapatan, dan terbukanya peluang mata pencaharian baru bagi sebagian kecil anggota kelompok tani.

\section{KESIMPULAN}

Berdasarkan hasil dan pembahasan mengenai Pemberdayaan Masyarakat dalam Rehabilitasi Hutan dan Lahan Melalui Program Kebun Bibit Rakyat di Desa Sumberrejo Kecamatan Tempel Kabupaten Sleman ini, dapat diambil ambil beberapa kesimpulan sebagai berikut :

1. Bentuk-bentuk upaya pemberdayaan masyarakat dalam Program KBR yang telah dilakukan seperti : a. pemberian kewenangan kepada masyarakat; b. pemberian dana dan insentif kegiatan; c. pendidikan dan latihan; d. bimbingan teknis; e. pendampingan; $f$. pengembangan kesempatan berusaha dan g. pengembangan akses, ternyata mampu meningkatkan kapasitas kelompok tani. Peningkatan kapasitas kelompok tani itu terutama pada aspek-aspek yang meliputi aspek teknis, aspek kelembagaan, aspek administrasi serta aspek kewirausahaan.

2. Hasil positif lain dari upaya pemberdayaan masyarakat dalam Program KBR ternyata mampu mengatasi 2 (dua) kendala dalam RHL sekaligus yaitu di satu sisi masyarakat yang kurang berdaya atau tidak mempunyai kemampuan dalam penanganan lahan kritis menjadi masyarakat yang berdaya, di sisi lain kemampuan pemerintah yang terbatas 
dalam penanganan lahan kritis, sangat terbantu dengan peran aktif masyarakat dalam kegiatan RHL.

3. Hasil dan analisis partisipasi masyarakat dalam Program KBR di Desa Sumberrejo Kecamatan Tempel Kabupaten Sleman menunjukkan :

a. Pada tahap perencanaan, tingkat partisipasi masyarakat untuk variabel perencanaan program berada pada level informing dan untuk perencanaan implementasi kegiatan pada level delegated power. Untuk variabel pengambilan keputusan dalam perencanaan ini tingkat partisipasi masyarakat berada pada level consultation;

b. Pada tahap pelaksanaan, tingkat partisipasi masyarakat untuk variabel mobilisasi tenaga berada pada level delegated power. Untuk variabel penyelesaian masalah tingkat partisipasi masyarakat berada pada level consultation;

c. Tahap monitoring dan evaluasi yang masing-masing dengan variabel monitoring berada pada level partnership, sedangkan untuk evaluasi berada pada level consultation.

Hal ini menunjukkan tingkat partisipasi masyarakat yang tinggi terutama pada variabel perencanaan implementasi kegiatan pada tahap perencanaan dan variabel mobilisasi tenaga pada tahap pelaksanaan yang berada pada level delegated power yaitu level ke-7 dari 8 (delapan) tingkatan partisipasi menurut Arnstein.

4. Untuk tingkat keberhasilan penanaman, dengan melihat prosentase realisasi luas areal tanam yang mencapai $100 \%$ berarti termasuk kriteria berhasil ( $\geq 80 \%$ ); sedangkan realisasi pertumbuhan tanaman yang mencapai $99,10 \%$ berarti termasuk kriteria berhasil $(\geq 60 \%$ untuk penilaian tahap I).

5. Program KBR berimplikasi terhadap potensi peningkatan kesejahteraan masyarakat berupa peningkatan jumlah kekayaan/asset berupa pohon dan potensi tanaman bibit KBR sebagai tambahan pendapatan pada saat panen nanti. Selain itu, terbukanya peluang mata pencaharian baru yang berupa usaha pembibitan tananam bagi sebagian kecil anggota kelompok tani.

\section{DAFTAR PUSTAKA}

Adisasmita, Rahardja. 2006. Pembangunan Pedesaan dan Perkotaan. Yogyakarta : Graha Ilmu. Agung R, Mohammad. 2001. Kemiskinan di Perkotaan. Semarang. Unissula Press.

Arnstein, Sherry. 1969. A Ladder Citizen of Participation. JAIP. Vol. 35 No. 4 , July 1969. Dicetak ulang oleh Richard T. LeGates. 1999. The City Reader ; Second Edition. London : Rouledge.

Dahl, Robert. 1983. Democrazy and its critics. New Haven Comn. Yale University Press.

Hall, Antony et al. 1986. Community Participation, Social Development and State. London: Mathuen.

Nawir, Ani Adiwinata, dkk. 2008. Rehabilitasi Hutan di Indonesia : Akan Kemanakah Arahnya Setelah Lebih dari Tiga Dasa Warsa. Center for International Forestry Research (CIFOR), Bogor.

Paul, Samuel. 1987. Community Participation in Development Projects-The World Bank Experience. The Washington DC: The World Bank.

Peraturan Menteri Kehutanan Republik Indonesia Nomor P.70/Menhut-II/2008 tanggal 11 Desember 2008 tentang Pedoman Teknis Rehabilitasi Hutan dan Lahan Tahun 2008.

Peraturan Menteri Kehutanan Republik Indonesia Nomor P.12/Menhut-II/2011 tanggal 9 Maret 2011 tentang Pedoman Penyelenggaraan Rehabilitasi Hutan dan Lahan Tahun 2011.

Peraturan Menteri Kehutanan Republik Indonesia Nomor P.23/Menhut-II/2011 tanggal 8 April 2011 tentang Pedoman Teknis Kebun Bibit Rakyat. 
Prasetyo, Bambang dan Lina Miftahul Jannah. 2012. Metode Penelitian Kuantitatif-Teori dan Aplikasi. Jakarta: PT. Raja Grafindo Persada.

Suhartini, dkk. 2005. Model-model Pemberdayaan Masyarakat. Yogyakarta. Pustaka Pesantren. Sulistiyani, Teguh Ambar. 2004. Kemitraan dan Model-Model Pemberdayaan. Yogyakarta. Media Gaya.

Undang-Undang Republik Indonesia No. 7 Tahun 2004 tentang Sumber Daya Air. Tambahan Lembaran Negara Republik Indonesia No. 4377. 